\title{
用語解説
}

\section{ディリクレ過程混合モデル（Dirichlet Process Mixture Model）}

クラスタリング手法としてよく知られる k-means 法や Fuzzy c-means 法では, 事前にクラスタ数を与える必要がある。しかしなが ら, クラスタリング問題において，適切なクラス夕数を事前に予測することは困難であるし，クラス夕数が事前に分かっているの であれば, クラスタリングをわざわざ実行する意味はあまり感じられない.もちろん，これらの手法において，クラス夕数をハイ パーパラメータとして分割結果と同時に推定することも理論上不可能ではないが, 相当の計算時間を必要とすることが容易に想像 できる。ここでは, ディリクレ過程混合モデル（DPMM）を用いたクラスタリングについてユーザの視点から解説する。 DPMM を 用いたクラスタリングの最大の特徵は, 従前のクラスタリング手法と異なり, 事前にクラスタ数を指定しなくても, 適切に分割さ れたクラスタ群を獲得できることにある。 また，DPMM を用いたクラスタリングによって獲得できるのは，与えられたデータの分 割結果だけではない.DPMM では確率モデルを仮定してクラスタリングを行うが, 仮定した確率モデルのパラメータも同時に推定 される．例えば，正規分布を仮定すれば，各クラスタを生成する正規分布の中心（平均）と分散についても同時に推定される。し たがって，推定結果から獲得された混合確率分布を用いて，未知のサンプルがどのクラス夕に属するのかについても高精度に判定 できることになる。一方，DPMM を用いたクラスタリングのアルゴリズムとそこで用いられている数式を確かめると分かるが，ク ラスタ数を事前に与える必要がない代わりに，いくつかのハイパーパラメータについては事前に設定しなければならないことに気 づくこの点については, 深層学習においてハイパーパラメータチューニングが必要なのと同様に, 万能な手法というわけではな い. DPMMにおけるクラスタリングでは，ギブスサンプリングという手法を用いるのが一般的である。このとき，例えば，正規分 布を仮定したDPMM を用いたクラスタリングを行う場合，事前に設定すべきハイパーパラメータには，クラスタを分割しやすく するパラメータや，クラスタの平均に影響するパラメータ，各クラスタの分散に係るパラメータ等が存在する。当然ながら，各パ ラメータの設定值は，クラスタ分割の挙動に影響する。このようなハイパーパラメー夕設定が必要であるものの，それを差し引い ても，クラスタリング問題において，データの分割結果に決定的に効いてくるクラスタ数を事前に定める必要がないことは，非常 に魅力的と言える

(名古屋工業大学 大学院工学研究科 情報工学専攻 中村 剛士)

\section{デザイン思考（Design Thinking）}

思考法あるいはシンキングは, 何かしらの問題を解決するためのプロセスを意味する。その中の 1 つとしてデザイン思考 (Design Thinking）がある，デザイン思考とは，デザイナーの思考プロセスや物事の見方を用いて，顧客の持つニーズを的確に理解し，価值 を生み出す思考方法の 1 つである。デザイン思考自体はそれほど新しい言葉ではなく,古くはハーバート・サイモンの「The Sciences of the Artificial」に見られる。デザイン思考の特徵として，ユーザーの「体験」を尊重し，モノの形状や機能をよりよい形に設計す ることで問題の解決に向かう，という点があげられる。

デザイン思考のプロセスは，(1) 共感する（Empathize），(2) 定義する（Define），(3)アイディアを創造する (Ideate)，(4)プロト タイプをつくる (Prototype), (5) 検証する（Test), という5つのステップからなる（このステップについては, いくつかバリエー ションがある)。(1)では，ユーザーの観察やインタビューあるいは自身で体験することにより，その背景にある思考や感情に触れ， 情報を収集する。（2）では，（1）の情報をもとに解くべき問題を決定する。（3）では，ブレインストーミングなどを通じて解決のア イディアを出す。(4)では, 単純化したプロトタイプをつくる。このとき, 適切なサイズで素早くつくることが肝要とされている. (5)では, (4)のプロトタイプを検証する。このプロトタイプは完成ではなく, 発想の促進, 共感の深堀り, アイディアの妥当性を 検証するためのものである。そのため, これらのステップは 1 度とは限らず，繰り返すことで問題解決策を段階的に改善するもの である。デザイン思考は対象となる問題として，高性能化や高機能化など明確な答えが存在する場合は不向きとされている。一方 で，ユーザーが体験した不便を感じたポイントなどから生じる潜在的なニーズに対しては，幅広く適用できるとされている。ここ で潜在的なニーズとして特徴的な点の 1 つに極端なユーザーのニーズを取り上げる点がある。極端なユーザーのニーズを取り上げ ることで，主観的だが面白い解決策につながるというものである.

近年，再びデザイン思考が注目されているのは，ビジネスに拉ける新しい価值の創出や，教育に取り入れようという動きがある ことも一因にある

（静岡理工科大学 高野 敏明） 